\title{
The Impact of Wood, Cigarette and Marijuana Smoke on the Reproductive Health of Tandoor Occupants
}

\author{
Ghulam Nabi (Corresponding author) \\ M. Phil Scholar. Department: Animal sciences, Reproductive neuro-endocrinology Lab \\ Quaid-i-Azam University, (Islamabad) Pakistan \\ Tel: 92-345-811-2741Ｅ-mail: ghulamnabiqau@gmail.com
}

Muhammad Amin

M. Phil Scholar, Department of Zoology, University of Karachi, Pakistan

Tel: 92-315-902-0833Ｅ-mail: aminmuhammad013@yahoo.com

\author{
Jeena Urooj \\ MSc, Department of Zoology, University of Malakand \\ Chakdara, Dir (L), Khyber Pakhtunkhwa, Pakistan \\ E-mail: jeenaurooj@yahoo.com
}

\begin{abstract}
Muhammad Kamil
M. Phil Scholar, Department of Botany, University of Malakand, Pakistan Tel: 92-343-925-6626Ｅ-mail: mohammadkamil86@gmail.com
\end{abstract}

\begin{abstract}
Ayaz Ali Khan
Assistant Professor, Department of Biotechnology, University of Malakand

Chakdara, Dir Lower, Khyber pakhtunkhwa, Pakistan

Tel: 92-345-58860677Ｅ-mail: lalatejan@gmail.com
\end{abstract}

Received: May 21, 2014 Accepted: June 3, 2014

doi:10.5296/jbls.v5i2.5654 URL: http://dx.doi.org/10.5296/jbls.v5i2.5654 


\section{Abstract}

The objective of this study was to determine the effects of wood, cigarette and marijuana smoke on the reproductive health of tandoor occupants. A total of 100 male individuals were selected (50 control and 50 tandoor occupants). A standard questionnaire was designed regarding their age, economic status, marital status, fuel type, exposure time (per day), use of mask, addiction and reproductive health. Morning blood samples of $5 \mathrm{~mL}$ of the size were taken from all participants. Serums were obtained and analyzed for total serum testosterone concentration. Bio-check (USA) kit was used according to the manufacturer protocol and procedures for testosterone analysis. In control group the mean \pm SEM of total serum testosterone was $671.9 \pm 20.02 \mathrm{ng} / \mathrm{dl}$ where as in tandoor occupants it was $542.7 \pm 16.40 \mathrm{ng} / \mathrm{dl}$. There was a significant reduction $\left(\mathrm{P}^{* * * *}<0.0001\right)$ in total serum testosterone concentration in tandoor occupants as compared to control group. Reproductive health problems like, low libido, erection problems, infertility, decreased frequency for shaving and absent morning and nocturnal erection were common in tandoor occupants as compared to control group.

Wood, cigarette and marijuana smoke negatively affects testosterone concentration and lowers it significantly. This reduced testosterone concentration then produces ill effects like low libido, erection problems, infertility and absent morning and nocturnal erection.

Keywords: Libido, Infertility, Nocturnal

\section{Introduction}

Tandoor is a cylindrical clay oven used for cooking and baking in Bangladesh, Burma, Afghanistan, Iran, Turkey, India and Pakistan. The heat for a Tandoor is generated by a charcoal or wood fire, burning within the Tandoor itself, thus exposing the food to live-fire. Tandoor is used for cooking certain types of food such as, Tandoori chicken, chicken tikka and bread varieties like Tandoori Roti and Naan in the above countries (Ghulam et al., 2014).

The burning woods add toxic particulate matters (PM) into the air. Wood smoke in addition to particulate matter also emits dioxin, volatile organic compounds (VOCs), nitrogen oxides (NOx) and carbon monoxide (CO). VOCs may be either nauseating, noxious, and/or cancer causing. Polycyclic aromatic hydrocarbons (PAHs) include carcinogens such as benzopyrene, is also present in wood smoke. The chemical composition and total amounts of toxicants depend on how the wood is burned. It mostly depends upon the appliances used for wood burning. Lesser amount of toxicant is produced using high energy efficient wood burning appliances. Wood smoke PM contains wood tars, gases, dust, and ashes. The size of the particulate matter in air is lesser than 2.5 micron (Minnesota Pollution Control Agency, 2011).

Wood smoke exposure can cause cardiovascular events, coronary artery diseases, cerebro-vascular diseases, venous thrombo-embolism (Fraanchini, 2011) chronic obstructive pulmonary diseases (COPD) (Riddervold et al., 2011). During cooking PM concentration increases in kitchen, thus causing acute respiratory infection in children and lung cancer in women (Perez et al., 2010). 


\section{MlMacrothink}

Journal of Biology and Life Science ISSN 2157-6076 2014, Vol. 5, No. 2

Like wood smoke diesel exhaust is also the important cause of air pollution and contains complex mixture of vapor-phase compounds and particulate matters. Smoke particles consist of carbon cores that adsorb many organic compounds including polycyclic aromatic hydrocarbons, heterocyclic organic compounds, quinines, aldehydes, and aliphatic hydrocarbons (Schuetzle et al,. 1981; Schuetzle, 1983; Li et al., 2000). These particles also contain substances having anti-androgenic, anti-estrogenic and estrogenic properties. The sperm production is severely reduced in adult rats due to decreased number of sertoli cells, when exposed to smoke particles during fetal life (Takeda et al., 2004). Smoke particles are discharged into the atmosphere enters our body via skin, lungs or the intestinal tract and affect reproductive functions (Yoshida et al., 1999; Yoshida et al., 2002; Tsukue et al., 2004; Oberdörster et al., 2005 a Oberdörster et al., 2005 ; Yoshida et al., 2006; Ono et al., 2007). In developing mice it has been shown that exposure to diesel exhaust causes degeneration of leydig cells, increase the number of damaged seminiferous tubules, and reduce daily sperm production (DSP) (Yoshida et al., 1999).

Cigarette smoking affects badly adrenal, thyroidal, pituitary, pancreatic, testicular and ovarian functions (Stárka et al., 2005). Cigarette smoke disrupts fertility in both sexes, lowering testosterone level and negatively shift spermiogram parameters in male (Trummer et al., 2002). Cigarette smoking also causes erectile dysfunction in male (Natali et al., 2005; Corona et al., 2005).

In humans as well as in animals models low plasma testosterone, abnormal spermatogenesis and decreased weight of accessory sex organs have been reported in males using marijuana or methadone (Azizi et al., 1973; kolodny et al., 1974; Cicero et al., 1975; Huang et al., 1978). Unlike methadone marijuana acts both directly and indirectly decreasing plasma testosterone levels (Symons et al., 1976; Smith et al., 1978).

Tandoor occupants are exposed to a heavy wood smoke for years. Particulate matter and other gases accumulate in their shops due to lack of proper exhaust system. In addition to wood smoke exposure they are also addicted to cigarette and marijuana. The present study is designed to determine the effects of wood, cigarette and marijuana smoke on testosterone level and their resulting consequences in tandoor occupants.

\section{Materials and Methods}

\subsection{Informed Consent}

Before starting the study informed consent was obtained from all the participants. Enough information was given to them about the purpose of the study. They were also assured that the collected information's will be used only for scientific purposes.

\subsection{Study Area}

This study was conducted in district Lower Dir, Khyber pakhtunkhwa, Pakistan.

\subsection{Questionnaire}

A standard questionnaire was designed. Questions about their age, marital status, economic 


\section{Macrothink}

Journal of Biology and Life Science

ISSN 2157-6076

2014, Vol. 5, No. 2

conditions, type of fuel used, exposure time to wood smoke, addictions, use of mask and reproductive problems were asked for every participant.

\subsection{Participants}

A total of 100 male individuals were selected. Two groups were made. Control and exposed. Each group contains 50 participants. Control peoples were selected randomly from the same area. The age of both group participants ranges from 25 to 55 years and was divided into four age groups i.e. 25-34, 35-44, 45-49 and 50-55.

\subsection{Blood Sampling}

A morning $5 \mathrm{~mL}$ blood samples were taken from the brachial vein of all participants aseptically. Blood samples were collected in vacutainer tube containing no preservatives or additives. To prevent contamination of samples from smoke, collection tube and catheter site were covered. All the blood samples were centrifuged at $3200 \mathrm{rpm}$ for 15 minutes at $4{ }^{\circ} \mathrm{C}$. Serums were obtained and for latter analysis were stored at $-20^{\circ} \mathrm{C}$.

\subsection{Exclusion Criteria}

Participants with a history of tuberculosis, pneumonia, renal problems, hepatic problems, heart problems and individuals using medications were excluded from the study.

\subsection{Assay}

Testosterone enzyme immunoassay test kit, Bio-check (USA) was used for the determination of total serum testosterone level according to the manufacturer protocol and procedures.

\subsection{Statistics}

Software graph pad prism, version 6.03 (Graph Pad Software Inc., San Diego, CA, USA) was used for data analysis. All data were presented as mean \pm SEM. Unpaired t test was used for the comparison of both groups. $\mathrm{P}<0.05$ indicated the significant difference.

\section{Results}

\subsection{History}

History of both control and exposed group are summarized in Table 1. 
Table 1. History of control and Tandoor occupants

\begin{tabular}{|c|c|c|c|c|c|c|c|c|}
\hline $\begin{array}{c}\text { Age } \\
\text { Group (Years) }\end{array}$ & No. & $\begin{array}{c}\text { Economic } \\
\text { status }\end{array}$ & $\begin{array}{l}\text { Marital } \\
\text { Status }\end{array}$ & $\begin{array}{l}\text { Fuel } \\
\text { type }\end{array}$ & $\begin{array}{c}\text { Exposure } \\
\text { Time (per day) }\end{array}$ & $\begin{array}{c}\text { Addiction } \\
(\%)\end{array}$ & Mask & $\begin{array}{l}\text { Reproductive health } \\
\text { status }\end{array}$ \\
\hline $\begin{array}{c}\text { Exposed } \\
\mathbf{2 5 - 3 4} \\
\end{array}$ & 15 & Poor & $\begin{array}{c}03 \text { single } \\
12 \text { married }\end{array}$ & Wood & $\geq 9 \mathrm{hrs}$. & $\begin{array}{c}02 \text { Snuff } \\
13 C^{*}+M^{*}\end{array}$ & No & $\begin{array}{c}05 \text { low libido } \\
06 \text { LSF }^{*}\end{array}$ \\
\hline $35-44$ & 20 & Poor & $\begin{array}{l}05 \text { single } \\
15 \text { married }\end{array}$ & Wood & $\geq 9$ hrs. & $\begin{array}{c}04 \text { Snuff } \\
16 C^{*}+M^{*}\end{array}$ & No & $\begin{array}{c}05 \mathrm{EP}^{*} \\
03 \text { low libido } \\
02 \text { infertility } \\
05 \mathrm{AME}^{*}\end{array}$ \\
\hline $45-49$ & 10 & Poor & $\begin{array}{c}00 \text { single } \\
10 \text { married }\end{array}$ & Wood & $\geq 9$ hrs. & $\begin{array}{c}02 \text { Snuff } \\
08 C^{*}+M^{*}\end{array}$ & No & $\begin{array}{c}03 \text { infertility } \\
04 \text { low libido } \\
03 \mathrm{AME}^{*}\end{array}$ \\
\hline $50-55$ & 5 & Poor & $\begin{array}{c}00 \text { single } \\
05 \text { married }\end{array}$ & Wood & $\geq 9$ hrs. & $\begin{array}{c}01 \text { Snuff } \\
02 \mathrm{C}^{*}+\mathrm{M}^{*}\end{array}$ & No & $\begin{array}{l}01 \text { infertility } \\
04 \text { low libido }\end{array}$ \\
\hline $\begin{array}{c}\text { Control } \\
25-34\end{array}$ & 15 & Poor & $\begin{array}{c}05 \text { single } \\
10 \text { married }\end{array}$ & No & 00 & 02 Snuff & No & 00 \\
\hline $35-44$ & 20 & Poor & $\begin{array}{c}07 \text { single } \\
13 \text { married }\end{array}$ & No & 00 & 03 Snuff & No & 00 \\
\hline $45-49$ & 10 & Poor & $\begin{array}{c}00 \text { single } \\
10 \text { married }\end{array}$ & No & 00 & 03 Snuff & No & 01 infertility \\
\hline $50-55$ & 5 & Poor & $\begin{array}{c}00 \text { single } \\
05 \text { married }\end{array}$ & No & 00 & 00 Snuff & No & $01 \mathrm{EP}^{*}$ \\
\hline
\end{tabular}

$\mathrm{C}^{*}=$ Cigarette, $\mathrm{M}^{*}=$ Marijuana, $\mathrm{LSF}^{*}=$ Low Shaving Frequency, $\mathrm{EP}^{*}=$ Erection Problems, $\mathrm{AME}^{*}=$ Absent Morning Erection.

\subsection{Total Serum Testosterone Analysis in Control and Tandoor Occupants}

Testosterone were analyzed both in control and tandoor occupants. Their results are summarized in Table 2 . The results showed that testosterone level is significantly lower $\left(\mathrm{P}^{* * * *}<\right.$ 0.0001 ) in tandoor occupants as compared to control group.

Table 2 Total serum testosterone concentration in control and Tandoor occupants

$\mathrm{CI}^{*}=$ confidence interval

\begin{tabular}{|l|l|l|l|l|}
\hline Parameters & Control & $\begin{array}{l}\text { Tandoor } \\
\text { occupants } \\
\text { Mean } \pm \text { SEM }\end{array}$ & P5\% C.I* & value \\
\hline Total serum testosterone & $671.9 \pm 20.02(\mathrm{ngdl})$ & $\begin{array}{l}542.7 \pm 16.40 \\
(\mathrm{ng} / \mathrm{dl})\end{array}$ & -180.6 to -77.88 & $<0.0001$ \\
\hline
\end{tabular}

\section{Discussion}

Tandoor occupants are exposed to wood smoke, automobile emission as well as they also smoke cigarette. Most of them are also addicted to marijuana. The present study focuses on the reproductive health of these peoples.

Leydig cells take up smoke particles and have shown cytotoxicity in cultured cells in vitro (Don Porto Carero et al., 2001; Renwick et al., 2001; Hussain et al., 2005). Particulate matters 
and related organic compounds produce inflammatory responses in lungs, endothelial cells and alveolar macrophages (Hirano et al., 2003). These particulate matters causes repressions of the StAR (Steriodogenic Acute Regulatory protein) expression, thus affects the production of steroid hormone productions from leydig cells. This also causes Leydig cell degeneration, increase the number of damaged seminiferous tubules, and reduce daily sperm production (; Yoshida et al., 1999; Diemer et al., 2003; Murugesan et al., 2007). This has been reported that various factors like AP-1, C/EBPb, GATA4, and DAX-1 are responsible for the regulation of StAR gene expression. The induction of StAR in Leydig cells by nanoparticles may be associated with these factors. (Jana et al., 2008; Silverman et al., 2006; Manna et al., 2004). In rats particulates matters triggers the suppressions of several genes which are crucial for gonadogenesis. This also reduces expression of genes which encode enzymes that are responsible for androgenesis. Diesel particulate matters also contain polycyclic aromatic hydrocarbons that stimulate Ah receptors. It also contains substances that have anti-androgenic, anti-estrogenic and estrogenic activity. In rats exposure to heavy smoke during fetal life, reduces the expression of Ad4BP/SF-1 mRNA that ultimately affect gonadal development. Such rats have low daily sperm production due to insufficient number of sertoli cells (Takeda $e t$ al., 2004).

In rats this has been found that penile erection is badly affected by cigarette smoke. Cigarette smoke also reduces plasma testosterone level and the activity of nitric oxide synthase in corpus cavernosum, ultimately leading to erectile dysfunction (Zhan et al., 2009). In an experiment 12 rats were exposed to cigarette smoke generated by a machine and 12 were exposed to room air. Before and after plasma testosterone, Luteinizing Hormone (LH) and Follicle Stimulating Hormone (FSH) were measured by Elisa. Testes were also examined histologically. It was found that plasma testosterone reduces significantly in cigarette smoke exposed rats as compared to control. No significant changes were found for LH and FSH in both groups. However in histological examination of testes, fewer leydig cells and degeneration of the remaining cells were observed (Yardimci et al., 1997). Cigarette smoking reduces testosterone concentration (Alexandersen et al., 1996). Cigarette smoke contains nicotine that like cocaine stimulates mesolimbic dopamine system which increases extracellular dopamine concentration (Corrigall et al., 1992; Di Chiara, 2000; Watkins et al., 2000). This increase in dopamine suppresses reproduction by regulating the secretion of Gonadotropin Releasing Hormone (GnRH) negatively (Murphy et al., 1998; Mello and Mendelson, 2002).

Marijuana and its constituent delta-9-tetrahydrocannabinol (D-9-THC) affect the reproduction negatively by decreasing the level of testosterone (Okey and Truant 1975; Nashas, 1984). There are several evidences which confirm that marujana regulate the estrogen positively but androgen negatively. Different effects of marijuana suggest that different constituent affect the hormonal profile in a different way (Chakravarty et al., 1975; Dixit et al., 1975; Chakravarty et al., 1976; Solomon et al., 1976; Solomon and Cocchia, 1977; Solomon et al., 1977).

\section{Conclusions}

Chronic exposure to wood smoke, cigarette and marijuana, negatively regulate testosterone level. Low testosterone level then leads to ill effects such as infertility, low libido, erection 
problems, decreased frequency for shaving and absent morning and nocturnal erection. Tandoor occupants are advised to use mask during working hours, improve exhaust system and if possible replaced the wood by gas. Further studies are needed to analyze the effects of individual gases on reproductive system.

\section{References}

Alexandersen, P. Haarbo, J., \& Christiansen, C. (1996). The relationship of natural androgens to coronary heart disease in males: a review. Atherosclerosis, 125, 1-13. http://dx.doi.org/10.1016/0021-9150(96)05864-9

Azizi, F. Vagenakis, A., \& longcope, C. (1973). Decreased serum testosterone concentration in male heroin and methadone addicts. Steroids, 22, 467-72. http://dx.doi.org/10.1016/0039-128X(73)90002-0

Chakravarty, I. Sengupta, D. Bhattacharya, P., \& Ghosh, JJ. (1976). Effect of cannabis extract on the uterine monoamine oxidase activity of normal and estradiol treated rats. Biochemical pharmacology. 25, 377-378. http://dx.doi.org/10.1016/0006-2952(76)90335-X

Cicero, TJ. Bell, RD. Wiest, WG., \& Allison, JH. (1975). Functions of the male sex organs in heroin and methadone uses, N. Eng. J. Med, 292, 882-87. http://dx.doi.org/10.1056/NEJM197504242921703

Corona, G. Mannucci, E. Petrone, L. Ricca, v. Mansani, R. Cilotti, A. Balercia, G. Chiarini, v. Giommi, R. Forti, G., \& Maggi, M. (2005). Psychobiological correlates of smoking in patients with erectile dysfunction. Int j impot res, 17, 527-534. http://dx.doi.org/10.1038/sj.ijir.3901351

Corrigall, WA. Franklin, KBI. Coen, KM., \& Clarke, PBS. (1992). The mesolimbic dopamine system is implicated in the reinforcing effects of nicotine. Psychopharmacology, 107, 285-289. http://dx.doi.org/10.1007/BF02245149

Dichara. G. (2000). Role of dopamine in the behavioural actions of nicotine related to addiction. European Journal of pharmacology, 393, 295-314. http://dx.doi.org/10.1016/S0014-2999(00)00122-9

Diemer, T. Allen, JA. Hales, KH., \& Hales, DB. (2003). Reactive oxygen disrupts mitochondria in MA-10 tumor Leydig cells and inhibits steroidogenic acuten regulatory (StAR) protein and steroidogenesis. Endocrinology, 144, 2882-2891. http://dx.doi.org/10.1210/en.2002-0090

Dixit, VP. Gupta, CL., \& Agarwal, M. (1977). Testicular degeneration and necrosis induced by chronic administration of cannabis extract in dogs. Endokrinologie, 69, 299-305.

Don, PC. Hoet, PH. Verschaeve, L. Schoeters, G., \& Nemery, B. (2001). Genotoxic effects of carbon black particles, diesel exhaust particles, and urban air particulates and their extracts on a human alveolar epithelial cell line (A549) and a human monocytic cell line (THP-1). Environmental and Molecular Mutagenesis, 37, 155-163. http://dx.doi.org/10.1002/em.1023 


\section{Mll Macrothink}

Journal of Biology and Life Science ISSN 2157-6076 2014, Vol. 5, No. 2

Franchini, M., \& Mannucci, PM. (2011). Thrombogenecity and cardiovascular effects of ambient air pollution. Journal of the American College of Cardiology, 52(9), 719-26.

Ghulam, N. Jeena, U. Ayaz, AK. Ghazala, YZ. Mussarat, W., \& Saleem, UR. (2014). Effects of occupational exposure to wood smoke in Tandoor occupants. Journal of Biology and Life Sciences, 5(2) 37-47. http://dx.doi.org/10.5296/jbls.v5i2.4079

Hirano, S. Furuyama, A. Koike, E., \& Kobayashi, T. (2003). Oxidative-stress potency of organic extracts of diesel exhaust and urban fine particles in rat heart microvessel endothelial cells. Toxicology, 187, 161-170. http://dx.doi.org/10.1016/S0300-483X(03)00053-2

Huang, HFS. Nahas, GG., \& Hembree, WC. (1978). Morphological changes of spermatozoa during marijuana induced depression of human spermatogenesis, Presented at $62^{\text {nd }}$ annual meeting of FASEB, Atlantic city, N.J. april 9-14, abstract, 2761.

Hussain, SM. Hess, KL. Gearhart, JM. Geiss, KT., \& Schlager, JJ. (2005). In vitro toxicity of nanoparticles in BRL 3A rat liver cells. Toxicology in Vitro, 19, 975- 983. http://dx.doi.org/10.1016/j.tiv.2005.06.034

Jana, K. Yin, X. Schiffer, RB. Chen, JJ. Pandey, AK. Stocco, DM. Grammas, P., \& Wang, X. (2008). Chrysin, a natural flavonoid enhances steroidogenesis and steroidogenic acute regulatory protein gene expression in mouse Leydig cells. Journal of Endocrinology, 197, 315-323. http://dx.doi.org/10.1677/JOE-07-0282

Kolodny, RC. Masters, WH. Kolodner, RM., \& Toro, G. (1974). Depression of plasma testosterone levels after chronic intensive marijuana use. N. Eng. J. Med, 290, 872-74. http://dx.doi.org/10.1056/NEJM197404182901602

Li, N. Venkatesan, MI. Miguel, A. Kaplan, R. Gujuluva, C. Alam, J., \& Nel, A. (2000). Induction of heme oxygenase-1 expression in macrophages by diesel exhaust particle chemicals and quinones via the antioxidant-responsive element. Journal of Immunology, 165, 3393-3401. http://dx.doi.org/10.4049/jimmunol.165.6.3393

Manna, PR. Eubank, DW., \& Stocco, DM. (2004). Assessment of the role of activator protein-1 on transcription of the mouse steroidogenic acute regulatory protein gene. Molecular Endocrinology, 18, 558-573. http://dx.doi.org/10.1210/me.2003-0223

Mello, NK., \& Mendelson, JH. (2002). Cocaine, hormones and behavior: clinical and preclinical studies, in Hormones, Brain and Behavior (Pfaff, D.W., Arnold, AP., Etgen, A.M., Fahrbach, S.E., and Rubin, R.T., eds) Academic Press, New York, pp 665-745. http://dx.doi.org/10.1016/B978-012532104-4/50106-2

Minnesota Pollution Control Agency., (2011). Health Effects of Wood Smoke; Home, Air Quality and Pollutants, General Air Quality, Wood Smoke. http://www.Pca.state.mn.us/indexphp/air/aiqualityandpollutants/generalairquality/woodsmoke /healtheffectswoodmokhtml.

Murphy, LL. Munoz, RM. Adrian, BA., \& Villanu, MA. (1998). Function of cannabinoid receptors in the neuroendocrine regulation of hormone secretion. Neurobiol. Dis, 5, 432-446. 
http://dx.doi.org/10.1006/nbdi.1998.0224

Murugesan, P. Balaganesh, M. Balasubramanian, K., \& Arunakaran, J. (2007). Effects of polychlorinated biphenyl (Aroclor 1254) on steroidogenesis and antioxidant system in cultured adult rat Leydig cells. Journal of Endocrinology, 192, 325-338. http://dx.doi.org/10.1677/joe.1.06874

Nahas, GG. (1984) In: Nahas, G.G. (Ed.), Marihuana in Science and Medicine, Raven Press, New York, pp. 109-246.

Natali, A. Mondaini, N. Lombardi, G. Del, PG., \& Rizzo, M. (2005). Heavy smoking is an important risk factor for erectile dysfunction in young men. International journal of impotence research, 17, 227-230. http://dx.doi.org/10.1038/sj.ijir.3901275

Oberdörster, G. Maynard, A. Donaldson, K. Castranova, V. Fitzpatrick, J. Ausman, K. Carter, J. Karn, B. Kreyling, W. Lai, D. Olin, S. Monteiro-Riviere, N. Warheit, D., \& Yang, H. (2005)a. Principles for characterizing the potential human health effects from exposure to nano materials: elements of a screening strategy. Particle and Fibre Toxicology, 2, 8. http://dx.doi.org/10.1186/1743-8977-2-8

Oberdörster, G. Oberdörster, E. Oberdörster, J. (2005)b. Nanotoxicology: an emerging discipline evolving from studies of ultrafine particles. Environmental Health Perspectives, 113, 823-839. http://dx.doi.org/10.1289/ehp.7339

Okey, AB., \& Truant, GS. (1975). Cannabis demasculinizes rats but is not estrogenic. Life Sciences, 17, 1113-1118. http://dx.doi.org/10.1016/0024-3205(75)90332-X

Ono, N. Oshio, S. Niwata, Y. Yoshida, S. Tsukue, N. Sugawara, I. Takano, H., \& Takeda, K. (2007). Prenatal exposure to diesel exhaust impairs mouse spermatogenesis. Inhalation Toxicology, 19, 275-281. http://dx.doi.org/10.1080/08958370601069257

Perez, PR. Schil, MA., \& Riojas, RH. (2010). Respiratory health effects of indoor air pollution. International Journal of Tuberculosis and Lung Diseases, 14(9), 1079-86.

Renwick, LC. Donaldson, K., \& Clouter, A. (2001). Impairment of alveolar macrophage phagocytosis by ultrafine particles. Toxicology and Applied Pharmacology, 172, 119-127. http://dx.doi.org/10.1006/taap.2001.9128

Riddervold, IS. Bonlokke, JH. Molhave, L. Massling, A. Jenson, B. Gronborg, TK. Bossi, R. Forchhammer, L. Kiargaard, SK., \& Sigsgaard, T. (2011). Wood smoke in a controlled exposure experiment with human volunteers. Inhalation Toxicology, 23(5), 277-88. http://dx.doi.org/10.3109/08958378.2011.567401

Schuetzle, D. (1983). Sampling of vehicle emissions for chemical analysis and biological testing. $\quad$ Environmental Health Perspectives, 47, 65-80. http://dx.doi.org/10.3109/08958378.2011.567401

Schuetzle, D. Lee, FS., \& Prater, TJ. (1981). The identification of polynuclear aromatic hydrocarbon (PAH) derivatives in mutagenic fractions of diesel particulate extracts. 
International Journal of Environmental Analytical Chemistry, 9, 93-144. http://dx.doi.org/10.1080/03067318108071903

Silverman, E. Yivgi-Ohana, N. Sher, N. Bell, M. Eimerl, S., \& Orly, J. (2006). Transcriptional activation of the steroidogenic acute regulatory protein (StAR) gene: GATA-4 and CCAAT/enhancer-binding protein beta confer synergistic responsiveness in hormone-treated rat granulosa and HEK293 cell models. Molecular and Cellular Endocrinology, 252, 92-101. http://dx.doi.org/10.1016/j.mce.2006.03.008

Smith, CG. Besch, NF. Smith, RG., \& Besch, PK. (1978). Mechanism for the antigonadotropic actions of tetrahydrocanabinol (THC), Presented at $62^{\text {nd }}$ annual meeting of FASEB, Atlantic city, N.J. april 9-14, abstract, 2687.

Solomon, J. Cocchia, MA. (1977). Is delta-9-tetrahydrocannabinol estrogenic? Science, 195, 905-906.

Solomon, J. Cocchia, MA. Dimartino, R. (1977). Effect of delta-9- tetrahydrocannabinol on uterine and vaginal cytology of ovariectomized rats. Science, 195, 875-877. http://dx.doi.org/10.1126/science.841311

Solomon, J. Cocchia, MA. Gray, R. Shattuck, D., \& Vossmer, A. (1976). Uterotrophic effect of delta-9-tetrahydrocannabinol in ovariectomized rats. Science, 192, 559-561. http://dx.doi.org/10.1126/science. 1257790

Stárka, L. Hill, M., \& Králíková, E. (2005). Smoking and endocrine system. Diabetologie Metabolismus Endokrinologie Výživa, 8, 180-186.

Symons, AM. Telea, JD., \& Marks, V. (1976). Effects of tetrahydrocanabinol on the hypothalamic pituitary gonadal system in the maturing male rat. Journal of endocrinology, 68 , 43-44.

Takeda, K. Tsukue, N., \& Yoshida, S. (2004). Endocrine-disrupting activity of chemicals in diesel exhaust and diesel exhaust particles. Environmental Sciences, 11(1), 33-45.

Trummer, H., \& Habermann, H. (2002). The impact of cigarette smoking on human semen parameters and hormones. Human Reproduction, 17, 1554-1559. http://dx.doi.org/10.1093/humrep/17.6.1554

Tsukue, N. Yoshida, S. Sugawara, I., \& Takeda, K. (2004). Effect of diesel exhaust on development of fetal reproductive function in ICR female mice. Journal of Health Science, 50, 174-180. http://dx.doi.org/10.1093/humrep/17.6.1554

Virag, R. Bouilly, P., \& Frydman, D. (1985). Is impotence an arterial disorder? A study of arterial risk factors in 440 impotent men. Lancet, 1, 181-184. http://dx.doi.org/10.1016/S0140-6736(85)92023-9

Watkins, SS. Koob, GF., \& Markou, A. (2000). Neural mechanisms underlying nicotine addiction: acute positive reinforcement and withdrawal. Nicotine Tobacco Research, 2, 19-37. http://dx.doi.org/10.1080/14622200050011277 


\section{Macrothink}

Yardimci, S. Atan, A. Delibasi, T. Sunguroglu, K., \& Guven, Mc. (1997). Long-term effects of cigarette-smoke exposure on plasma testosterone, luteinizing hormone and follicle-stimulating hormone levels in male rats. British Journal of Urology, 79(1), 66-9. http://dx.doi.org/10.1046/j.1464-410X.1997.28314.x

Yoshida, M. Yoshida, S. Sugawara, I., \& Takeda, K. (2002). Maternal exposure to diesel exhaust decreases expression of Steroidogenic Factor-1 and mullerian inhibiting substance in the murine fetus. Journal of Health Science, 48, 317-324. http://dx.doi.org/10.1248/jhs.48.317

Yoshida, S. Ono, N. Tsukue, N. Oshio, S. Umeda, T. Takano, H., \& Takeda, K. (2006). In utero exposure to diesel exhaust increased accessory reproductive gland weight and serum testosterone concentration in male mice. Environmental Sciences, 13, 139-147.

Yoshida, S. Sagai, M. Oshio, S. Umeda, T. Ihara, T. Sugamata, M. Sugawara, I., \& Takeda, K. (1999). Exposure to diesel exhaust affects the male reproductive system of mice. International Journal of Andrology, 22, 307-315. http://dx.doi.org/10.1046/j.1365-2605.1999.00185.x

Zhan, XS. Wu, TP. Oyuang, H. Liu, XB., \& Cai, HL. (2009). Cigarette smoke affects sexual function of male rats. Zhonghua Nan Ke Xue, 15(9), 788-91.

Zimmerman, AM. Zimmerman, S., \& Raj, A. (1979). Effects of cannabinoids on spermatogenesis in mice. In: Nahas GG, Paton W, editors. Marihuana: biological effects. New York: Pergamon. p 407.

\section{Copyright Disclaimer}

Copyright for this article is retained by the author(s), with first publication rights granted to the journal.

This is an open-access article distributed under the terms and conditions of the Creative Commons Attribution license (http://creativecommons.org/licenses/by/3.0/). 